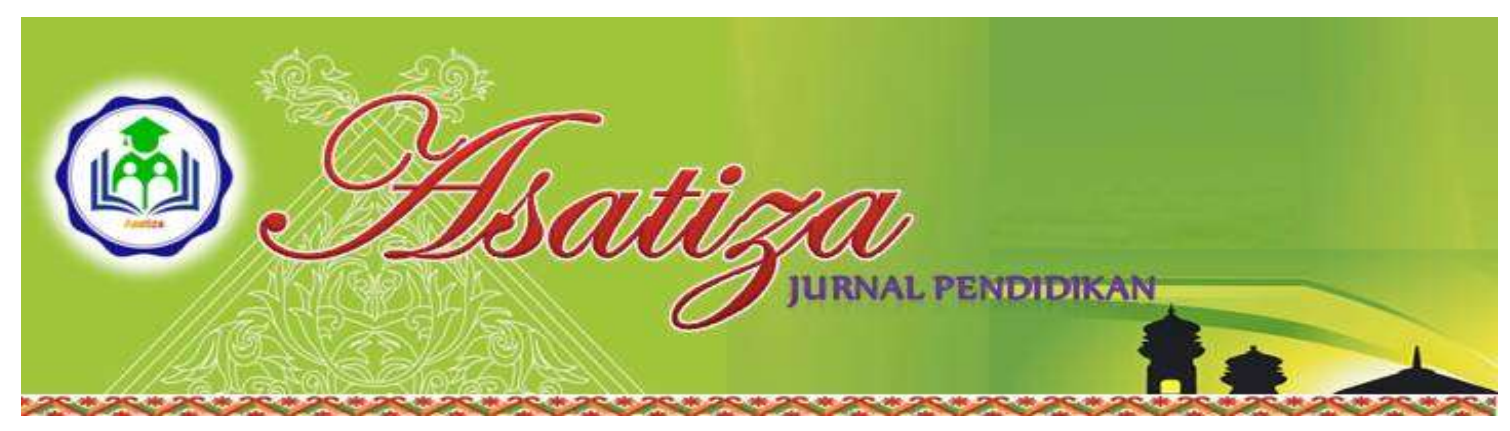

\title{
INTEGRASI PENDIDIKAN KARAKTER DALAM MATA KULIAH PENDIDIKAN PANCASILA DI PERGURUAN TINGGI \\ M. Ridhwan ${ }^{1}$, Deddy Yusuf Yudhyrta ${ }^{2}$ Anggi Yurisa ${ }^{3}$
}

\author{
${ }^{1}$ Dosen STAI Auliaurrasyidin Tembilahan, Indonesia \\ ${ }^{2}$ Dosen STAI Auliaurrasyidin Tembilahan, Indonesia \\ ${ }^{3}$ Mahasiswi STAI Auliaurrasyidin Tembilahan, Indonesia
}

\begin{abstract}
Abstrak
Pembahasan mengenai karakter merupakan hal penting dan mendasar. Baik atau buruknya karakter seseorang tercermin dalam sikap/tingkah lakunya dalam kehidupan seharihari. Melihat situasi di negara kita saat ini yang nampak pada buruknya tingkah laku warga negara, dari pemberitaan yang ada di berbagai media massa. Hampir setiap hari memberitakan tentang kejahatan yang dilakukan, baik itu kejahatan biasa maupun kejahatan yang luar biasa sebenarnya sudah sangat sulit untuk ditoleransi.

Penelitian ini menggunakan pendekatan kualitatif dengan metode studi kasus sedangkan teknilk pegumpulan datayaitu observasi, wawancara dan dokumentasi. Adapun responden adalah dosen Pendidikan Pancasila yaitu 2 orang. Pada penelitian ini, juga mencoba mengamati hambatan-hambatan yang dihadapi oleh dosen dalam mengintegrasikan konsep pendidikan karakter dalam tahap perencanaan, pelaksanaan, dan evaluasi pembelajaran. Integrasi pendidikan karakter dalam matakuliah Pancasila. Hal merupakan solusi yang dapat membangkitkan kembali peranPancasila sebagai mata kuliah yang merupakan leading sector dalam pengembangan karakter mahasiswa.
\end{abstract}

Kata Kunci: Pendidikan Pancasila, integrasi, karakter

\section{A. PENDAHULUAN}

\section{Latar belakang}

Secara etimologis istilah karakter berasal dari bahasa Latin kharakter, kharassaein, dan kharax, dalam bahasa Yunanicharacter dari kata charassei, yang berarti membuat tajam dan membuat dalam. Depdiknas dalam Gunawan, menguraikan bahwa: Istilah berkarakter artinya memiliki karakter, memiliki kepribadian, berprilaku, bersifat, bertabiat, dan berwatak. Individu yang berkarakter baik atau unggul adalah seseorang yang berusaha melakukan hal-hal yang baik terhadap Tuhan Yang Maha Esa, dirinya, sesama, lingkungan, bangsa dan negara, serta dunia internasional pada umumnya dengan mengoptimalkan potensi (pengetahuan) dirinya dan disertai dengan kesadaran, emosi, dan motivasinya (perasaannya) ${ }^{1}$.

Hal tersebut juga senada dengan yang disebutkan oleh Aqib bahwa berdasarkan kajian nilai-nilai agama,

${ }^{1}$ Gunawan, H. 2012. Pendidikan Karakter (Konsep dan Implementasi). Bandung: Alfabeta.h. 2 
norma-norma sosial, peraturan/hukum, etika akademik, dan prinsip-prinsip HAM, telah teridentifikasi butir-butir nilai yang dikelompokkan menjadi nilai utama, yaitu nilai-nilai perilaku manusia dalam hubungannya dengan Tuhan Yang Maha Esa, diri sendiri, sesama manusia, dan lingkungan serta kebangsaan. Adapun secara rinci nilai-nilai tersebut adalah:

a. Hubungannya dengan Tuhan, yaitu religius. Pikiran, perkataan, dan tindakan seseorang yang diupayakan selalu berdasarkan pada nilai-nilai Ketuhanan dan/atau ajaran agamanya.

b. Hubungannya dengan diri sendiri, yaitu jujur, bertanggung jawab, bergaya hidup sehat, disiplin, kerja keras, percaya diri, berjiwa wirausaha, berpikir logis, kritis, kreatif, dan inovatif, mandiri, ingin tahu, cinta ilmu

c. Hubungannya dengan sesama, yaitu sadar akan hak dan kewajiban diri dan orang lain, patuh pada aturan-aturan sosial, menghargai karya dan prestasi orang lain, santun, demokratis.

d. Hubungan dengan lingkungan, yaitu peduli akan sosial dan lingkungan ditunjukkan dengan sikap dan tindakan selalu berupaya mencegah kerusakan pada lingkungan alam sekitarnya, dan mengembangkan upaya-upaya untuk memperbaiki kerusakan alam yang sudah terjadi dan selalu ingin memberi bantuan bagi orang lain dan masyarakat yang membutuhkan. e. Nilai kebangsaan, yaitu nasionalis dan menghargai keberagaman. ${ }^{2}$

Pembentukan kecerdasan afektif yang berujung pada sikap/karakter individu dapat dilakukan dengan pendidikan karakter banyak para ahli yang memberikan pengertian mengenai pendidikan karakter. Zubaedi menyebut kan bahwa pendidikan karakter adalah usaha sengaja (sadar) untuk mewujudkan kebajikan, yaitu kualitas kemanusiaan yang baik secara objektif, bukan hanya baik untuk individu perseorangan tetapi juga baik untuk masyarakat secara keseluruhan. $^{3}$

Sejalan dengan pengertian di atas, Creasy dan Zubaedi juga memberikan pemahaman mengenai pendidikan karakter sebagai upaya mendorong peserta didik tumbuh dan berkembang dengan kompetensi berpikir dan berpegang teguh pada prinsip-prinsip moral dalam hidupnya serta mempunyai keberanian melakukan yang benar, meskipun dihadapkan pada berbagai tantangan.

Pendidikan karakter harus dimulai dengan proses penanaman pengetahuan atau kecerdasan pada individu mengenai hal-hal baik yang layak dilakukan maupun tidak dan pengetahuan yang ada dapat diaplikasikan pada bentuk sikap. Dengan begitu, individu diharapkan dapat memiliki kekuatan diri dalam mempertahankan hal-hal baik tersebut meskipun ada godaan dari luar. Hal-hal

${ }^{2}$ Aqib, Z. 2012. Pendidikan Karakter Di Sekolah (Membangun Karakter DanKepribadian Anak). Bandung: Yrama Widya.h.40

${ }^{3}$ Zubaedi. 2012. Desain Pendidikan Karakter (Konsepsi Dan Aplikasinya Dalam Lembaga Pendidikan). Kencana Prenada Media Group: Jakarta. h.15 
baik yang dilakukan individu tersebut tidak hanya untuk dirinya sendiri tetapi juga untuk orang lain dan lingkungan nya. Hal ini sesuai dengan konsep mengenai karakter bahwa karakter yang ada pada individu tidak hanya berupa kebaikan yang berguna bagi dirinya tetapi juga kebaikan untuk orang lain dan lingkungan sekitarnya.

Pendidikan karakter diberikan kepada mahasiswa itu adalah suatu kewajiban untuk membentuk prilaku mahasiswa yang baik dan sesuai dengan nilai-nilai masyarakat. Dalam memberi kan pendidikan moral terjadi perkembangan moral yang pada siswa. Perkembangan moral merupakan suatu hasil kemampuan yang semakin berkembang untuk memahami kenyataan sosial atau untuk menyusun strategi dan mengintegrasi pengalaman sosial. ${ }^{4}$

Perkembangan moral adalah perkembangan yang berkaitan dengan aturan dan konvensi mengenai apa yang seharusnya dilakukan oleh manusia dalam interaksinya dengan orang lain. ${ }^{5}$ Dengan kemampuan yang semakin berkembang dalam mengitegrasi pengalaman, diharapkan siswa dapat menerapkan pendidikan moral yang diberikan itu dalam kehidupan seharihari dengan baik. Adapun tahap-tahap perkembangan menurut Kolhberg sebagai berikut ${ }^{6}$ :

a. Tingkat Pra-Konvensional. Pada tahap ini seseorang sangat tanggap terhadap aturan-aturan kebudayaan

${ }^{4}$ C.Asri Budiningsih, Pembelajaran Moral, (Jakarta: PT Renika Cipta, 2013), h. 82.

${ }^{5}$ Desmita, Psikologi Perkembangan Peserta Didik, (Bandung: PT. Remaja Rosdakarya, 2012), h. 259.

${ }^{6}$ Op.cit., h 29-31. dan penilaian baik atau buruk, tetapi ia menafsirkan baik atau buruk ini dalam rangka maksimalisasi kenikmatan atau akibat-akibat fisik dari tindakannya (hukuman fisik, penghargaan, tukar-menukar kebaik an). Kecendrungan utamanya dalam interaksi dengan orang lain adalah menghindari hukuman atau mencapai maksimalisasi kenikmatan (Hedonis tis). Tingkat ini dibagi 2 tahap : (1). Orientasi Hukuman dan Kepatuhan. Pada tahap ini, baik atau buruknya suatu tindakan ditentukan oleh akibatakibat fisik yang akan dialami, sedangkan arti atau nilai manusiawi tidak diperhatikan. Menghindari hukuman dan kepatuhan terhadap penguasa dinilai baik pada dirinya. (2). Orientasi Instrumentalistis. Pada tahap ini tindakan seseorang selalu diarahkan untuk memenuhi kebutuhannya sendiri dengan memperalat orang lain. Hubungan antara manusia dipandang seperti hubungan dagang. Unsur-unsur keterbukaan, kesalingan dan tukar menukar merupakan prinsip-prinsip kesalingannya adalah, "Kamu mencakar punggungku dan aku akan ganti mencakar punggungmu".

b. Tingkat Konvensional. Pada tahap ini seseorang menyadari dirinya sebagai individu di tengah-tengah keluarga, masyarakat dan bangsanya. Keluarga, masyarakat, bangsa dinilai memiliki kebenarannya sendiri, kerena jika menyimpang dari kelompok ini akan terisolasi. Maka itu, kecendrungan orang yang pada tahap ini adalah menyesuaikan diri dengan aturanaturan masyarakat dan mengiden- 
tifikasikan dirinya terhadap kelompok sosialnya. Kalau pada tingkat Prakonvensional perasaan dominan adalah takut, pada tingkat ini perasaan dominan adalah malu. Tingkat ini terdiri dari 2 tahap : (1). Orientasi Kerukunan atau Orientasi Good BoyNice Girl. Pada tahap ini orang berpandangan bahwa tingkah laku yang baik adalah yang menyenangkan atau menolong orang-orang lain serta diakui oleh orang-orang lain. Orang cendrung bertindak menurut harapanharapan lingkungan sosialnya, hingga mendapat pengakuan sebagai orang baik. tujuan utamanya, demi hubungan sosial yang memuaskan, maka ia pun harus berperan sesuai dengan harapan-harapan keluarga, masyarakat atau bangsanya.(2). Orientasi Ketertiban Masyarakat. Pada tahap ini tindakan seseorang didorong oleh keinginannya untuk menjaga tertib legal. Orientasi seseorang adalah otoritas, peraturanperaturan yang ketat dan ketertiban sosial. tingkah laku yang baik adalah memenuhi kewajiban, mematuhi hukum, menghormati otoritas, dan menjaga ketertiban sosial merupakan tindakan moral yang baik pada dirinya.

c. Tingkat Pasca-Konvensional. Pada tahap ini orang bertindak sebagai subyek hukum dengan mengatasi hukum yang ada. Orang pada tahap ini bahwa hukum merupakan kontrak sosial demi ketertiban dan kesejahteraan umum, maka jika hukum tidak sesuai dengan martabat manusia, hukum dapat dirumuskan kembali. Perasaan yang muncul pada tahap ini adalah rasa bersalah dan yang menjadi ukuran keputusan moral adalah hati nurani. Tingkata ini terdiri dari 2 tahap (1). Orientasi Kontrak Sosial. Tindakan yang benar pada tahap ini cendrung ditafsirkan sebagai tindakan yang sesuai dengan kesepakatan umum.(2). Orientasi Prinsip Etis Universal. Pada tahap ini orang tidak hanya memandang dirinya sebagai subyek hukum, tetapi juga sebagai pribadi yang harus dihormati..

Pendidikan moral ditujukan untuk memagari mahasiswa dalam melakukan perbuatan buruk yang tidak sesuai dengan norma-norma yang ada baik itu dalam bermasyarakat, berbangsa dan bernegara. Pendidikan moral dapat disampaikan dengan metode langsung atau tidak langsung. Metode langsung mulai dengan penentuan prilaku yang dinilai baik, sebagai upaya indoktrinasi berbagai ajaran. Caranya dengan memusatkan perhatian secara langsung pada ajaran tersebut, lewat mendiskusikan, mengilustrasikan, menghafal kan, dan mengucapknya. Dalam pendidikan moral anak disampaikan melalui penanaman pengertian tingkah laku yang benar atau salah, atau baik buruk oleh orang tua, guru, atau orang dewasa lainnya.Adapun stategi dalam pendidikan moral adalah sebagai berikut ${ }^{7}$ :

a. Pendidikan moral dapat dilakukan dengan menetapkan pelaksanaan pendidikan agama, karena pada nilainilai dan ajaran agama pada akhirnya

${ }^{7}$ Abuddin Nata, Manajemen Pendidikan: Mengatasi Kelemahan Pendidikan Islam di Indonesia, Jakarta: Kencana, h. 214-216. 
ditujukan untuk membentuk moral yang baik.

b. Pendidikan agama yang dapat menghasilkan perbaikan moral harus diubah dari model pengajaran agama kepada pendidikan agama.

c. Pendidikan moral dapat dilakukan dengan pendekatan yang bersifat integred, yaitu dengan melibatkan seluruh disiplin ilmu pengetahuan.

d. Pendidikan moral harus melibatkan guru.

e. Pendidikan moral harus didukung oleh kemampuan, kerja sama yang kompak dan usaha sungguh-sungguh dari keluarga atau rumah tangga,sekolah dan masyarakat.

f. Pendidikan moral harus menggunakan seluruh kesempatan, berbagai sarana termasuk teknologi modern. Kesempatan berkreasi, pameran, kunjungan berkemah, dan sebagainya harus digunakan sebagai peluang untuk membina moral. Demikian pula dengan menggunakan berbagai sarana seperti mesjid, musholla, lembaga-lembaga pendidikan, surat kabar, majalah, radio, televisi, internet dan sebagainya dapat digunakan untuk pembinaan moral.

Prilaku yang ada pada individu tidak timbul dengan sendirinya, tetapi timbul sebagai akibat dari adanya stimulus atau rangsang yang mengenai individu tersebut. Prilaku merupakan jawaban atau respon terhadap stimulus yang ada, sedangkan respon merupakan fungsi yang tergantung pada stimulus dan individu. Prilaku merupakan jawaban atau respon terhadap stimulus yang mengenainya. ${ }^{8}$ Komponen prilaku terdiri dari kesiapan seseorang untuk bereaksi atau kecendrungan untuk bertindak terhadap objek. ${ }^{9}$

Menurut pandangan Behaviorisme, prilaku adalah segala sesuatu yang dilakukan dan dapat dilihat secara langsung. ${ }^{10}$ Prilaku adalah segala sesuatu atau tindakan yang sesuai dengan nilainilai tata/cara yang ada dalam masyarakat. Tindakan-tindakan yang dilakukan oleh mahasiswa sesuai dengan nilai-nilai norma ataupun nilai yang ada dalam masyarakat yang sudah ada sebelumnya dalam suatu kelompok sosial masyarakat, terbagi menjadi:

a. Klasifikasi Prilaku Menurut Gagne. Gagne dalam teorinya tentang kondisi-kondisi belajar mengelompok kan prilaku kedalam delapan kelas dari tipe belajar sederhana sampai pada belajar yang kompleks adalah sebagai berikut: ${ }^{11}$

1) Signal Learning. Dalam jenis belajar ini individu memperoleh respon terkondisi terhadap signal tertentu.

2) Stimulus Response Learning. Belajar S-R dapat digunakan untuk memperoleh keterampilan verbal dan gerakan fisik dengan cara menghubungkan stimulus dengan respon.

\section{${ }^{8}$ Op. Cit, h.11.}

'Inge Hutagalung, Pengembangan Kepribadian Tinjuan Praktis Menuju Pribadi Positif, (Jakarta: PT. Macan Jaya Cemerlang, 2007), h. 53.

${ }^{10}$ Agus Suprijono, 2012, Cooperative Learning Teori dan Aplikasi PAIKEM, Yogyakarta : Pustaka Pelajar.h. 17.

${ }^{11}$ Oemar Hamalik, 2011. Proses Belajar Mengajar, Jakarta : Bumi Aksara. Ibid, h. 77-78. 
3) Chaining. Dalam jenis belajar ini seseorang merangkaikan bersamasama S-R yang telah dipelajari sebelumnya. Rangkaian itu mungkin melibatkan reaksi-reaksi fisik.

4) Verbal Association. Asosiasi verbal yang tersederhana adalah kegiatan penanaman suatu objek yang melibatkan suatu rantai dari dua rangkaian.

5) Discrimination Learning. Dalam tipe belajar ini siswa harus mempelajari respon-respon yang berbeda-beda bagi stimulus yang mungkin membingungkan. Siswa belajar membedakan rantai motorik dan rantai verbal yang diperolehnya.

6) Belajar Konsep (Concept Learning). Dalam mempelajari konsep kita merespons stimulus yang karakteristiknya abstrak, misalnya warna, bentuk. Posisi, dan nomor sebagai lawan dari sifat fisik konkret.

7) Rule Learning. Aturan (rule) adalah rangkaian konsep. Dalam mempelajari aturan itu kita menghubungkan dua atau lebih konsep. Kita harus mempelajari dua atau lebih sebelum mempelajari keteraturan yang lebih tinggi. Dengan mempelajari komponen konsep-konsep dan aturan, guru dapat menggunakan pengajaran verbal dalam memimpin siswa untuk meletakkan aturan-aturan bersama-sama.

8) Problem Solving. Dalam perangkat peristiwa yang disebut pemecahan masalah siswa menggunakan aturan-aturan untuk mencapai beberapa tujuan. Bila tujuan telah tercapai, siswa telah mempelajari sesuatu lebih kemudian mampu melaksanakan prilaku baru yang menggunakan pengetahuan yang baru pula. Pemecahan masalah menurut peristiwa internal yang biasa disebut berfikir.

b. Teori Insting ${ }^{12}$. Menurut Mc. Dougall prilaku itu disebabkan karena insting. Insting merupakan prilaku yang innate, prilaku bawaan, dan insting akan mengalami perubahan karena pengalaman.

c. Teori Dorongan (Drive Theory). Teori ini bertolak pada pandangan bahwa organisme (siswa) itu mempunyai dorongan-dorongan atau drive tertentu. Dorongan-dorongan ini berkaitan dengan kebutuhan-kebutuh an organisme yang mendorong organisme berprilaku. Bila siswa berprilaku dan dapat memenuhi kebutuhannya, maka akan terjadi pengurangan atau reduksi dari dorongan-dorongan tersebut.

d. Teori Insentif (Incentive Theory). Teori ini bertitik tolak pada pendapat bahwa prilaku organisme (siswa) itu disebabkan karena adanya insentif. Dengan insentif akan mendorong organisme berbuat atau berprilaku. Insentif juga disebut sebagai reinforcement ada yang positif dan ada yang negatif. Reinforcement yang positif adalah berkaitan dengan hadiah, sedangkan reinforcement yang negatif berkaitan dengan

${ }^{12}$ Bimo Walgito, 2010, Pengantar Psikologi Umum, Yogyakarta: CV. Andi Offset., h. 19-21. 
hukuman. Reinforcement positif akan mendorong siswa dalam berbuat, sedangkan reinforcement yang negatif berkaitan dengan hukuman. Reinforce ment positif akan mendorong siswa dalam berbuat, sedangkan reinforce ment yang negatif akan dapat menghambat dalam siswa dalam berprilaku. Ini berarti prilaku timbul karena adanya insentif atau reinforcement.

e. Teori Atribusi. Teori ini dikemukakan oleh Fritz Heider yang ingin menjelaskan tentang sebab-sebab prilaku seseorang. Apakah prilaku disebabkan oleh oleh disposisi (misalnya motif, sikap, dan sebagainya) atau disebabkan oleh keadaan eksternal.

f. Teori Kognitif. Apabila seseorang harus memilih prilaku mana yang mesti dilakukan, maka yang bersangkutan akan memilih alternatif prilaku yang akan membawa manfaat yang sebesar-besarnya bagi yang bersangkutan. Dengan kemampuan memilih ini berarti kemampuan berfikir seseorang akan dapat melihat apa yang dihadapi pada waktu sekarang dan juga melihat ke depan.

Pada konteks makro, program pendidikan karakter bangsa dapat digambarkan sebagai berikut.

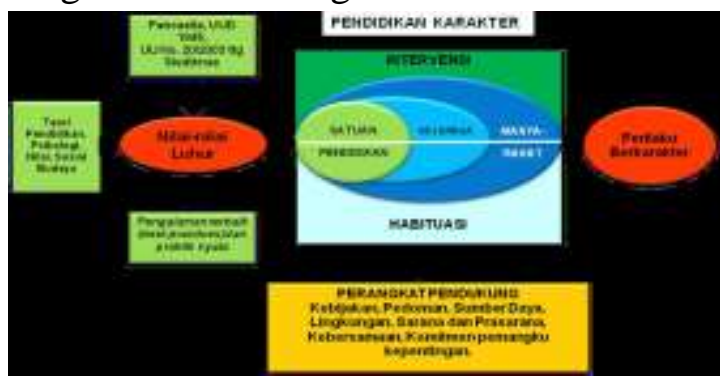

Sumber. Kebijakan Nasional Pembangunan Karakter Bangsa TAHUN 2010-2025

\section{B. METODOLOGI}

Penelitian ini merupakan penelitian deskriptif kualitatif dengan metode studi kasus, karena mengacu pada prosedur penelitian yang menghasilkan data-data deskriptif atau penggambaran. Menurut Wina Sanjaya penelitian deskriptif kualitatif adalah penelitian yang bertujuan untuk menggambarkan secara utuh dan mendalam tentang realitas sosial dan berbagai fenomena yang terjadi di masyarakat yang menjadi subjek penelitian sehingga tergambarkan ciri, karakter, sifat, dan model dari fenomena tersebut. ${ }^{13}$

Digunakan metode penelitian ini, untuk menggali secara mendalam mengenai pengintegrasian pendidikan karakter dalam matakuliah Pendidikan Pancasila mulai dari tahap perencanaan, pelaksanaan, dan evaluasi. Peneliti melakukan analisis terhadap berbagai data yang didapatkan di lapangan. Adapun pegumpulan data dilakukan melalui berbagai teknik, yaitu observasi proses pembelajaran di kelas, wawancara dengan paradosen, serta melihat dokumentasi berupa silabus dan RPP yang digunakan oleh dosensebagai responden yaitu 2 orang dosen pendidikan Pancasila di STAI Auliaurrasyidin Tembilahan - Riau

\section{PEMBAHASAN}

Berdasarkan grand design pendidikan karakter Tahun 2010, diuraikan bahwa pada lingkungan sekolah terdapat empat pilar yang dapat dijadikan sebagai wadah penanaman

13 Wina Sanjaya, Penelitian Pendidikan: Jenis, Metode dan Prosedur, (Jakarta: Kencana, 2013), Ed. 1, h. 47. 
nilai- nilai karakter. Diantara keempat wadah tersebut salah satunya adalah melalui kegiatan belajar-mengajar di kelas yang diintegrasikan pada setiap matakuliah termasuk dalam hal ini yaitu matakuliah Pendidikan Pancasila. Setiap matakuliah yang diberikan pada mahasiswa di kelas diharapkan dapat memberikan dampak pembentukan karakter kepada mahasiswa. Dalam hal ini ada yang disebut dengan dampak instruksional dan dampak pengiring (nurturant effect).

Matakuliah Pendidikan Pancasila sesungguhnya merupakan salah satu mata kuliah yang kaya akan nilai-nilai karakter. Pendidikan Pancasila merupa kan salah satu leading sector dari pembelajaran berkarakter. Oleh karena itu tujuan karakter yang ditetapkan dalam Matakuliah Pendidikan Pancasila sesungguhnya merupakan dampak instruksional yang ingin dicapai bukan hanya sebatas dampak pengiring saja. Namun, pada kenyataan saat ini Matakuliah Pendidikan Pancasila seakan menjadi matakuliah yang tidak dianggap begitu penting karena Mata kuliah Pendidikan Pancasila hanya sebatas pada kegiatan menghapal materi dankurang mampu menjalankan fungsinya sebagai leadingsector dari pendidikan karakter. Pada tahap perencanaan pembelajaran, maka yang harus dilakukan adalah mempersiapkan silabus dan Rencana Pelaksanaan Pembelajaran (RPP). Oleh karena itu, pada penelitian ini penulis melakukan analisis terhadap silabus dan RPP yang dipersiapkan oleh dosen dalam mendukung Matakuliah Pendidikan Pancasila berkarakter di kelas. Perencanaan pada pembelajaran yang dituangkan pada RPP memiliki fungsi yang besar dalam menyukseskan pendidikan karakter dalam pembelajar an. Hal ini didukung oleh pendapat yang dikemukakan oleh Mulyasa yang menguraikan bahwa sedikitnya terdapat dua fungsi RPP dalam menyukseskan pendidikan karakter di sekolah, yaitu: ${ }^{14}$

Fungsi perencanaan. Dalam implementasi pendidikan karakter di sekolah, RPP berfungsi untuk mendorong setiap guru agar lebih siap dalam melakukan kegiatan pembelajar an, membentuk kompetensi, dan karakter peserta didik dengan perencana an yang matang.

Fungsi pelaksanaan. Untuk menyukseskan implementasi pendidikan karakter di sekolah RPP harus disusun secara sistematik dan sistematis, utuh dan menyeluruh, dengan beberapa kemungkinan penyesuaian dalam situasi pembelajaran yang actual. Dalam hal ini, materi standar yang dikembangkan dan dijadikan bahan kajian oleh peserta didik harus disesuaikan dengan kondisidan kebutuhan lingkungan, sekolah, dan daerah.

Pendapat Mulyasa tersebut juga diperkuat oleh pendapat Joseph dan Leonard dalam Mulyasa, yang mengemukakan bahwa "Teaching without adequate ewritten planning is sloppy and almost always ineffective, because the teacher has not thought out exactly what to do and how to do it." 15 . Kedua pendapat tersebut jelas menegaskan bahwa seorang guru yang

\footnotetext{
${ }^{14}$ Mulyasa. 2013. Manajemen Pendidikan Karakter. Jakarta: Bumi Aksara. h. 82

${ }^{15}$ Mulyasa. 2013. Manajemen Pendidikan Karakter. Jakarta: Bumi Aksara. h. 85
} 
akan memberikan pembelajaran di kelas harus membuat perencanaan mengenai hal-hal apa saja yang akan dilaksanakan dalam pembelajaran di kelas. Begitu pentingnya perencanaan pembelajaran ini, maka pembuatan rencana tersebut harus dilakukan secara baik dan benar.

Pada penelitian integrasi pendidikan karakter dalam Matakuliah Pendidikan Pancasila di STAI Auliaurrasyidin Tembilahan, peneliti juga melakukan pengumpulan data dokumentasi berupa silabus dan RPP yang dipersiapkan oleh Dosen. Berdasarkan silabus dan RPP yang peneliti dapatkan dari Dosen, peneliti melihat bahwa dosen sudah melakukan modifikasi pada beberapa komponen dalam pembuatan silabus dan RPP. Pada pembuatan silabus dan RPP dosen telah melakukan modifikasi dengan menambahkan langsung jenis karakter yang ingin dicapai setelah kegiatan pembelajaran. Hal ini sesuai dengan pedoman dari pembuatan RPP berkarakter yang dikemukakan dalam Gunawan bahwa salah satu hal yang harus dimodifikasi dalam silabus untuk memfasilitasi terjadinya pembelajaran yang membantu peserta didik mengembangkan karakter adalah "Penambahan dan / atau modifikasi indikator pencapaian sehingga ada indikator yang terkait dengan pencapaian peserta didik dalam hal pembentukan karakter. ${ }^{16 "}$ Selain itu, berkaitan dengan modifikasi dalam RPP, peneliti juga melihat bahwa di dalam RPP yang dibuat oleh guru, telah dilakukan modifikasi dalam indicator pembelajaran. Pada RPP

${ }^{16}$ Gunawan, H. 2012. Pendidikan Karakter (Konsep dan Implementasi). Bandung: Alfabeta. h. 226 guru telah menambahkan secara khusus jenis karakter yang ingin dicapai dalam kegiatan pembelajaran. Hal ini menunjukkan bahwa guru telah melakukan modifikasi RPP berkarakter yang sesuai dengan pedoman dari Depdiknas yang dikutip dalam Mulyasa hal yang harus ditempuh oleh guru dalam mengembangkan RPP berkarakter, yaitu:

Mengidentifikasi atau mengelom pokkan karakter yang ingin dicapai setelah proses pembelajaran. Identifikasi karakter perlu dilakukan sebaik-baiknya karena kesalahan dalam mengidentifikasi karakter dapat mengaburkan makna dan hakikat pembelajaran. Terdapat beberapa hal yang perlu diperhatikan dalam mengidentifikasi karakter, yaitu hendak nya mengandung unsur proses dan produk, bersifat spesifik dan dinyatakan dalam bentuk perilaku nyata, mengan dung pengalaman belajar yang diperlu kan untuk mencapai karakter tersebut, pembentukan karakter seringkali membutuhkan waktu relative lama, harus realistis dan dapat dimaknai sebagai kegiatan atau pengalaman belajar tertentu. ${ }^{17}$

Selanjutnya, hal lain yang dapat dilihat dari silabus berkarakter yang dipersiapkan oleh guru, peneliti melihat bahwa guru belum begitu melakukan modifikasi dalam komponen teknik penilaian karena pada silabus tersebut tidak ada penambahan/modifikasi pada komponen teknik penilaian. Untuk komponen ini guru sudah mencoba untuk memilih bentuk penilaian tes tertulis dan pengamatan terhadap sikap

${ }^{17}$ Mulyasa. 2013. Manajemen Pendidikan Karakter. Jakarta: Bumi Aksara. h. 102 
siswa. Namun, bentuk penilaian tertulis yang diberikan oleh guru hanya sebatas latihan-latihan soal yang menurut peneliti hanya mampu melihat kemam puan kognitif mahasiswa saja, sedang kan untuk pengamatan sikapnya guru hanya melakukan sendiridan kurang melibatkan peran aktif siswa. Misalnya dengan mengajak siswa melakukan penilaian terhadap diri sendiri atau bias juga menggunakan bentuk penilaian antar teman. Oleh karena itu peneliti merasa bahwa guru masih kurang maksimal dalam melakukan modifikasi silabus pada komponen kegiatan pembelajaran dan teknik penilaiannya. Seharusnya guru lebih melakukan perubahan dan kreatifitas pada tahap tersebut karena kedua komponen tersebut merupakan bagian penting yang harus dimodifikasi agar mendukung pembelajaran berkarak ter. Hal ini sesuai dengan pedoman pengembanagan silabus berkarakter Depdiknas yang dikutip dalam Gunawan bahwa untuk memfasilitasi terjadinya pembelajaran yang membantu peserta didik mengembangkan karakter perlu dilakukan ${ }^{18}$ :

Penambahan dan/atau modifikasi kegiatan pembelajaran sehingga memuat kegiatan pembelajaran yang mampu mengembangkan nilai-nilai karakter yang diinginkan.

Penambahan dan/atau modifikasi teknik penilaian sehingga ada teknik penilaian yang dapat mengembangkan dan/atau mengukur perkembangan karakter.

${ }^{18}$ Gunawan, H. 2012. Pendidikan Karakter (Konsep dan Implementasi). Bandung: Alfabeta. h. 226
Selanjutnya analisis dokumentasi pada RPP, peneliti juga mengamati komponen-komponen lain, seperti pemilihan metode, kegiatan pembelajar an, media, sumber belajar, dan evaluasi pembelajaran. Pada RPP dengan Standar Kompetensi menganalisis sistem politik diIndonesia yang terdiri atas empat kompetensi dasar dan diajarkan selama enam kali pertemuan, peneliti melihat bahwa pada setiap pertemuan guru sudah merencanakan untuk menggunakan cukup beragam sumber, media, dan metode pembelajaran. Pada setiap pertemuan guru menggunakan cukup beragam sumber belajar seperti bukubuku Matakuliah Pendidikan Pancasila, internet, informasi/berita dari berbagai media baik cetak ataupun elektronik, dan juga menggunakan sumberbelajar langsung, yaitu siswa diarahkan untuk belajar langsung dari lingkungan. Selanjutnya, guru juga menggunakan beragam media pembelajaran untuk mendukung berhasilnya pengembangan karakter siswa. media yang rencananya akan digunakan oleh guru adalah powerpoint/slide sebagai sarana guru untu menjelaskan materi, selanjutnya guru akan menampilkan berbagai video, film-film pendek, gambar, selanjutnya juga media internet untuk membantu siswa memperdalam informasi yang berkaitandengan materi yang sedang dipelajari.

Kemudian, berkaitan dengan metode pembelajaran, sama hal nya dengan media dan semberbelajar. Guru juga telah merencanakan beragam metode pembelajaran dalam mendukung keberhasilan pengembang an karakter siswa. Adapun metodenya adalah ceramah, 
kegiatan tanya jawab, diskusi kelompok, problem solving atau pemecahan masalah, menonton video/film, observasi langsung kelapangan, dan inkuiri. Berbagai metode yang direncanakan oleh guru tersebut diharapkan dapat membantu mengembangkan karakter siswa. Secara tidak langsung karakterkarakter yang ingin dikembangkan dapat diintegrasikan pada metode-metode pembelajaran yang digunakan. Peng gunaan metode yang beragam dan mampu meningkatkan keaktifan dan kreativitas siswa disarankan untuk mendukung keberhasilan pengembang an karakter siswa. Hal ini sesuai dengan pedoman penyusunan RPP berkarakter dari Depdiknas yang dikutip oleh Mulyasa bahwa:

Penentuan metode pembelajaran erat kaitannya dengan pemilihan strategi pembelajaran yang paling efektif danefisien dalam memberikan pengalaman belajar yang diperlukan untuk membentuk karakter peserta didik. Dalam setiap pembelajaran dan pembentukan karakter peserta didik, guru dapat menggunakan berbagai variasi metode, dan berbagai variasi media untuk mencapai tujuan pembelajaran. Dalam hal ini guru diharapkan dapat memilih dan menggunakan berbagai metode dan media pembelajaran yang dapat menumbuhkann aktivitas dan kreativitas peserta didik ${ }^{19}$.

Namun, walaupun pada kompone nmedia, metode, sumber belajar guru telah merencanakan dengan baik, tetapi pada komponen evaluasi atau

${ }^{19}$ Mulyasa. 2013. Manajemen Pendidikan Karakter. Jakarta: Bumi Aksara. h. 102 penilaiannya peneliti melihat bahwa guru belum merencanakan teknik penilaian yang beragam.

Pada RPP dosen hanya merencanakan bentuk penilaian tes tertulis dan pengamatan sikap siswa saja. Pada penilaian dengan tes tertulis peneliti mengamati bahwa soal-soal tertulis yang dipersiapkan olehguru hanya sebatas pada pengukuran kognitif saja. Sedangkan pengamatan sikap terhadap siswa dilakukan hanya oleh dosen saja dan tidak melibatkan mahasiswa, seperti penilaian diri yang dilakukan oleh mahasiswa dan penilaian antar teman. Penilaian yang dapat membantu mengukur perkembangan karakter siswa tersebut diantaranya adalah melalui observasi/pengamatan sikap siswa selama proses atau setelah pembelajaran baik yang dilakukan oleh dosen ataupun juga melibatkan mahasiswa melalui penilaian diri atau penilaian antar teman. Selanjutnya bentuk penilaian juga bisa berupa anecdit record, skala bertingkat, wawancara terhadap siswa, dan portofolio.

Selanjutnya, Berdasarkan data dari observasi dan hasil wawancara, maka peneliti mengamatibahwa pada langkahlangkah Mata kuliah Pendidikan Pancasila yang dilakukan, dosen telah berupaya untuk mengintegrasikan nilainilai karakter yang hendak dicapai dari kegiatan pembelajaran. Mulai dari tahap pendahuluan, inti, dan penutup. Pada tahap pendahuluan dosen melakukan hal-hal yang mampu menyisipkan nilainilai karakter pada setiap tahapnya, seperti dosen mempersiapkan keadaan kelas dan mahasiswa sebelum memulai 
pelajaran, kemudian mengabsensi dan menanyakan kabar siswa, melakukan apersepsi dengan menanyakan kepada mahasiswa materi sebelumnya dan mencoba menghubung kan dengan materi sekarang, dosen juga menyampaikan kompetensi dan cakupan materiyangakan dipelajari.

Selanjutnya, tahapan kegiatan inti. Pada tahapan kegiatan inti dosen mencoba menyampaikan materi pembelajaran dengan berusaha melibatkan mahasiswa secara aktif. Inti dari pembelajaran berkarakter adalah mahasiswa dilibatkan untuk lebih banyak terlibat, jadi pembelajaran tidak hanya berpusat kepada dosen melainkan kepada mahasiswa. Pada langkahlangkah pembelajaran dikegiatan inti dosent elah mencoba untuk lebih banyak melibatkan mahasiswa, misalnya dalam penyampaian materi dosen hanya menyampaikan secara umum saja dan siswa diarahkan untuk menggali sendiri informasi secara mendalam dari berbagai sumber, selanjutnya guru sering menampilkan berbagai video atau film yang berhubungan dengan materi. Pada kegiatan ini, Dosen mengarahkan mahasiswa untuk mengamati tayangan video atau film dan diminta memberikan komentarnya. Hal lain juga yang dilakukan oleh dosen pada kegiatan inti adalah mahasiswas ering dilatih untuk berdiskusi memecahkan permasalahan secara bersama-sama. Hal tersebut sesuai dengan teori mengenai pembelajaran aktif dalam Pendidikan Pancasila yang dikemukakan oleh Cholisin bahwa pembelajaran aktif dalam Pendidikan Pancasila antara lain dilaksanakan melalui kegiatan sebagai berikut: mencari informasi dari berbagai sumber seperti bukuteks, suratkabar, majalah, tokoh masyarakat ,membaca dan menelaah(studi pustaka), mendiskusikan, mempresentasikan, Memberi tanggapan, memecahkan masalah atau kasus, mengamati/mengobservasi, Mensimulasi kan, Mendemonstrasikan, Memberikan contoh. ${ }^{20}$

Selanjutnya, tahapan terakhir dalam pembelajaran, yaitu kegiatan penutup. Pada kegiatan penutup seorang dosen juga harus mampu mengintegrasikan nilai-nilai karakter. Berdasarkan data observasi dan wawancara, dosen telah melakukan kegiatan penutup dengan baik dalam membantu mengembang kan karakter siswa karena apa yang dilakukan oleh guru pada kegiatan penutup telah sesui dengan teori yang dikemukakan oleh Gunawan yang menyatakan bahwa pada kegiatan penutup pembelajaran berkarakter terdapat beberapa langkah yang harus dilakukan, yaitu ${ }^{21}$ :

Bersama-sama dengan peserta didik dan/atau sendiri membuat rangkuman /simpulan pelajaran (contoh nilai yang ditanamkan mandiri, kritis, kerjasama, kritis, logis)

Melakukan penilaian dan/atau refleksi terhadap kegiatan yang sudah dilaksanakan secara konsisten dan terprogram (contoh nilai yang ditanmkan jujur, mengetahui kelebihan dan kekurangan)

${ }^{20}$ Cholisin. 2011. Pengembangan Karakter Dalam Materi Pembelajaran Pkn. Yogyakarta: Universitas Negeri Yogyakarta, h. 6-7

${ }^{21}$ Gunawan, H. 2012. Pendidikan Karakter (Konsep dan Implementasi). Bandung: Alfabeta. h. 233-234 
Memberikan umpan balik terhadap proses dan hasil pembelajaran (contoh nilai yang ditanamkan saling menghargai, percayadiri, santun, kritis, logis)

Merencanakan kegiatan tindak lanjut dalam bentuk pembelajaran remedi, program pengayaan, layanan konseling dan/atau memberikan tugas, baik tugas individual maupun kelompok sesuai dengan hasil belajar peserta didik

Menyampaikan rencana pembelajar an pada pertemuan berikutnya. Langkahlangkah yang disebutkan diatas, telah dilakukan oleh guru pada kegiatan penutup, dimana guru telah mengajak siswa untuk menyimpulkan materi pembelajaran bersama-sama, kemudian memberikan kesempatan kepada siswa untuk mengomentari atau memberikan penilaian terhadap kegiatan pembelajar an yang telah dilalui, sertabisa memberikansaran untuk kegiatan pembelajaran selanjutnya, dan terakhir dosen selalu menyampaikan materi selanjutnya dan menutup dengan salam.

Selanjutnya, Berdasarkan data yang peneliti dapatkan melalui observasi langsung kegiatan pembelajaran Pendidikan Pancasila, dan wawancara dari dosen, peneliti melihat bahwa bentuk evaluasi atau penilaian yang dilakukan dalam pembelajaran Pendidikan Pancasila belum begitubaik karena ketika pembelajaran di kelas, peneliti melihat bahwa dosen tidak menggunakan teknik penilaian yang beragam. Dosen hanya melakukan penilaian berupa penilaian terhadap tugas mahasiswa dalam bentuk tertulis, selanjutnya dosen juga melakukan penilaian dengan memberikan pertanya an langsung kepada mahasiswa diakhir pelajaran yang menurut penelitihanya sebatas pada pengukuran kognitif saja, selanjutnya dosen sudah melakukan penilaian terhadap sikap mahasiswa selama proses pembelajaran. Namun, belum dilakukan ecara terus-menerus.

Pada penelitian ini, peneliti juga mencoba mengamati hambatanhambatan yang dihadapi oleh dosen dalam mengintegrasikan konsep pendi dikan karakter dalam tahap perencanaan, pelaksanaan, dan evaluasi pembelajaran.

Pada tahap perencanaan terkadang guru diminta untuk melengkapi hal-hal yang bersifat administratif sehingga penyusunannya tidak terlalu baik. Selanjutnya pada tahap pelaksanaan kendalanya adalah waktu. Terkadang untuk melakukan bentuk pembelajaran yang ideal dalam mendukung pengembangan karakter siswa dibutuhkan waktu yang lebih banyak. Selanjutnya permaslahan juga berasal dari luar. Banyaknya contoh-contoh yang tidak baik di luar membuat guru kesulitan untuk menjelaskan hal-hal baik yang ada kepada siswa.

\section{KESIMPULAN}

Dalam mengantisipasi permasalahan pada tahap perencanaan, biasanya guru mencoba memaksimal kan pada tahap pelaksanaan saja meskipun silabus dan RPP yang disiapkan tidak sempurna. Selanjutnya mengatasi permasalahan kurangnya waktu, dosen sebisa mungkin mengedit kegiatan yang ada disesuaikan dengan waktu yang tersedia. Sedangkan untuk permasalahan banyaknya contoh-contoh yang kurang baik diluar membuat dosen 
harus lebih ekstra memberikan penguatan kepada mahasiswa mengenai nilai-nilai yang baik.

\section{REFERENSI}

A.Ubaedillah dan Abdul Rozak, 2013, Pendidikan Kewarganegaraan (Civic Education) Demokrasi, Hak Asasi Manusia Dan Masyarakat Madani, Jakarta: Kencana Prenadamedia Group.

Abuddin Nata, 2012, Manajemen Pendidikan : Mengatasi Kelemahan Pendidikan Islam di Indonesia, Jakarta : Kencana.

Agus Suprijono, 2012, Cooperative Learning Teori dan Aplikasi PAIKEM, Yogyakarta : Pustaka Pelajar.

Ahmad Tafsir, 2012, Filsafat Pendidikan Islami :Integrasi Jasmani, Rohan, dan Kalbu Memanusiakan Manusia, Bandung :Pt.Remaja Rosdakarya.

Aqib, Z. 2012. Pendidikan Karakter Di

Sekolah (Membangun Karakter Dan Kepribadian Anak). Bandung: Yrama Widya.

Bimo Walgito, 2010, Pengantar Psikologi Umum, Yogyakarta : CV. Andi Offset.

Budimansyah, D. 2012. DimensiDimensi Praktik Pendidikan Karakter. Bandung: Widya Aksara Press.

Budiningsih Asri, 2013.Pembelajaran Moral, (Jakarta: PT. Renika Cipta, 2013),

Cholisin. 2011. Pengembangan Karakter Dalam Materi Pembelajaran Pkn. Yogyakarta: Universitas Negeri Yogyakarta.

Darmadi, H. 2010. Pengantar Pendidikan Kewarganegaraan. Bandung: Alfabeta

Darmayati Zuchadi, 2008, Humanisasi Pendidikan : Menentukan Kembali Pendidikan yang Manusiawi, Jakarta : Bumi Aksara.
Deddy Yusuf Yudhyarta, 2017, Pentingnya Pendidikan Kewarga negaraan Di Perguruan Tinggi, Pekanbaru : UR Press.

Desmita, 2012,Psikologi Perkembangan Peserta Didik, Bandung : PT. Remaja Rosdakarya.

Elly M. Setiadi, 2005, Pendidikan Pancasila Untuk Perguruan Tinggi, Jakarta : PT.Gramedia Pustaka Utama.

Franz Magnis Suseno, 1987, Etik Dasar : Masalah-Masalah Pokok Filsafat Moral, Yogyakarta : Kanisius.

Gunawan, H. 2012. Pendidikan Karakter (Konsep dan Implementasi). Bandung: Alfabeta.

H.B. Siswanto, 2011, Pengantar Manajemen, Jakarta : Bumi Aksara.

Hasan Basri, 2009, Filsafat Pendidikan Islam, Bandung : PT. Pustaka Setia.

Inge Hutagalung, 2007,Pengembangan Kepribadian Tinjuan Praktis Menuju Pribadi Positif, Jakarta : PT. Macan Jaya Cemerlang.

Komalasari, K. 2010. Pembelajaran kontekstual (konsep dan aplikasi). Bandung: PT Refika Aditama.

Lickona, T. 2012. Character Matters. Jakarta: PT Bumi Aksara.

Moh. Haitami Salim dan Syamsul Kurniawan, 2012, Studi Ilmu Pendidikan Islam, Jogjakarta : ArRuzz Media

Mulyasa. 2013. Manajemen PendidikanKarakter. Jakarta: Bumi Aksara.

Oemar Hamalik, 2011, Proses Belajar Mengajar, Jakarta : Bumi Aksara.

Syamsu Yusuf, 2009, Psiklogi Perkembagan Anak dan Remaja,Bandung : PT. Remaja RosdaKarya.

Zubaedi. 2012. Desain Pendidikan Karakter (Konsepsi Dan Aplikasinya Dalam Lembaga Pendidikan). Kencana Prenada Media Group: Jakarta. 